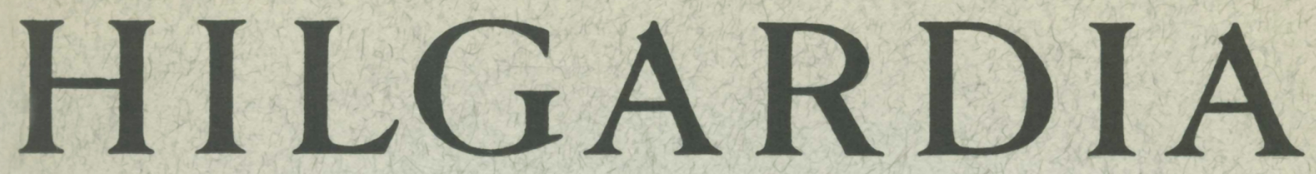

A Journal of Agricultural Science Published by the California Agricultural Experiment Station

\title{
HILGARD AND \\ CALIFORNIA VITICULTURE
}

\author{
MAYNARD A. AMERINE
}

UNIVERSITY OF CALIFORNIA - BERKELEY, CALIFORNIA 


\section{$\begin{array}{lllllllll}H & \text { I } & \text { L } & G & A & R & D & \text { I } & \text { A }\end{array}$}

A Journal of Agricultural Science Published by

the California Agricultural Experiment Station

\begin{tabular}{lll}
\hline VoL. 33 & JULY, 1962 & No. 1 \\
\hline
\end{tabular}

\section{HILGARD AND CALIFORNIA VITICULTURE ${ }^{1}$ \\ MAYNARD A. AMERINE ${ }^{2}$}

\section{FOREWORD}

Eugene Waldemar Hilgard was born in Germany in 1833 and spent his early years in Belleville, St. Clair County, Illinois. When he was sixteen he went to Europe to study geology and chemistry in Switzerland and Germany, receiving his doctorate in chemistry from Heidelberg. In 1855 he became State Geologist of Mississippi, and later Professor of Chemistry and Professor of Experimental and Agricultural Chemistry at the University of Mississippi. From 1873 to 1875 he was Professor of Geology and Natural History at the University of Michigan.

After this, he came to the University of California as Professor of Agriculture and Botany, later becoming Director of Experiment Stations and Dean of the College of Agriculture. He became Emeritus in 1906 and died at the age of eighty-three in 1916.

Hilgard's significant contributions to soil science have recently been recorded in the book $\boldsymbol{E}$. W. Hilgard and the Birth of Modern Soil Science by Professor Hans Jenny (1961). The purpose of this paper is to review Hilgard's significant contributions to California viticulture and enology. Although the Prohibition period removed many of the results of Hilgard's work from California vineyards, the influence of his far-reaching and systematic attack on the problems of California's grape and wine industry can still be detected today.

\section{INTRODUCTION}

Before he came to California in 1875, Hilgard had little, if any, professional training in viticulture or enology. Yet during the twenty years which followed he made permanent contributions to the viticultural industry of the state and established the University of California as an important center of research in viticulture and enology. This is particularly noteworthy for a man who had many other professional interests.

Hilgard was not without knowledge of grapes and wines prior to his work in California. This was undoubtedly a result of his father's interest in the

${ }^{1}$ Submitted for publication July 13, 1961.

${ }^{2}$ Professor of Enology and Enologist in the Experiment Station, Davis. 
subject. In a biographical sketch of his brother he speaks of their father as being a viticulturist at Belleville, Illinois, from 1835 to $1851 .^{3}$ However, in a biography of his father, Hilgard described him only as a jurist, publicist, and poet (Jenny, 1961). In a lecture on phylloxera (1876) Hilgard writes of handling diseased vines in southern Illinois thirty years earlier at a time when his father was among the first to attempt the culture of German grape varieties in that region. He had also observed phylloxera in the South, presumably in Mississippi between 1855 and 1873. The possibilities of grape growing in Mississippi were also considered in his 1860 report in that state. A letter ${ }^{4}$ from his father in 1871 also praises Hilgard's experiments in growing grapes in Mississippi. Hilgard's father was at Heidelberg at this time and the letter also indicates that he was growing grapes there as a hobby. During a later controversy with $\mathrm{C}$. A. Wetmore, a winery owner and executive of the California Board of State Viticultural Commissioners, Hilgard wrote to Pohndorff, an early associate of his in the Berkeley viticulture experiments (December 22, 1884), "I have known about wines and wine-making before he [Wetmore] was in his teens."

Since Hilgard was two years old when his parents eame from Germany in 1835 , he had no childhood memories of German viticulture. However, he went to Germany while in his teens and did not return until 1854 or 1855 , when he was about twenty. Some of his letters contain references to German wines. Little mention is made of the wines of France or other European countries, although he probably knew something of Spanish wines and of the influence of climate on wines from his long visit to Malága.

Actually, Hilgard's earliest professional writing on viticulture or enology was probably for the 1878 edition of Johnson's New Universal Cyclopedia, to which he contributed articles on vine culture and wines and wine making. In his first report as Professor of Agriculture at the University of California in 1877 he hardly mentioned grapes. But in his report of 1879 viticulture occupied a prominent place. His interest may have been stimulated in 1878 when he was a member of the group selected to judge wines at the Mechanies' Institute of San Francisco. From 1880 until 1896 he devoted a considerable portion of his time to viticultural activities.

Hilgard wrote the first scientific reports on phylloxera in this state. Varieties of wine grapes were his main viticultural interest from 1880 until 1896. In connection with his varietal studies he conducted extensive experiments on fermentation. At various times he reported on minor aspects of the field, such as grape syrup, pasteurization, vineyard soils and grape diseases. Finally, his views on temperance, though mainly expressed in private correspondence, were related to his interest in fine wines.

\footnotetext{
${ }^{3}$ The Hilgard signet ring contained a vine shoot.

4 The letters quoted herein are in the possession of Professor Hans Jenny on the Berkeley campus of the University of California.
} 


\section{PHYLLOXERA $^{5}$}

Phylloxera vitifoliae Fitch (now called Dactylosphaera vitifoliae Shimer) is a root louse which is endemic to the eastern and central United States, especially the Mississippi Valley. The native species of Vitis growing there are relatively resistant to it; however, the roots of the European grapes Vitis vinifera, grown both in Europe and California, are vulnerable and will eventually die from its attack. Phylloxera was found in Europe in the 1850's and during the next fifty years destroyed virtually all the vineyards of France, Spain and Italy, resulting in devastating economic loss. It was also identified on vines near Sonoma, California, in $1873 .^{\circ}$

Soon after Hilgard arrived in California in the spring of 1875 , he was asked to give a lecture before the State Vinicultural Association on phylloxera. In the two years since the insect had been identified in the Sonoma Valley, the danger of its presence had become apparent and reports of its devastation in Europe led to fears that it might spread throughout California. This speech, "The Phylloxera or Grape Vine Louse," was published as Bulletin 23 of the University of California (not of the College of Agriculture) in January, 1876. It was subsequently reprinted twice and is the obvious source of later popular articles on the subject by other authors.

In his lecture Hilgard reviewed methods of control and correctly noted the effectiveness of carbon bisulfide, submersion, and resistant stocks. ${ }^{7}$ Since the first two methods were expensive and not always applicable, Hilgard placed his main hopes on resistant stocks. In advocating this technique, he was following extensive work being done by French viticulturists. The subject was new to California, however, and Hilgard, in summarizing the latest and most reliable information, performed a real service for the California industry.

Active work on phylloxera evidently did not get under way until four or five years later, perhaps because, in contrast to European conditions, phylloxera spread slowly in California. In his 1875 speech, Hilgard warned against this complacency and outlined a plan for energetic action. A further reason for this lapse of time was probably the fact that Hilgard himself lacked funds for experimental facilities until the experimental work in viticulture was authorized by the California legislature in 1880 .

As early as 1880, in the revised edition of his lecture on phylloxera, Hilgard tentatively suggested that Vitis californica, one of the native wild species, might prove a useful stock. That he felt experiments were necessary is clear from his letter to Drummond, a Sonoma vineyardist, on March 3, 1880, asking that Drummond test the resistance of $V$. californica in a phylloxera-infested

\footnotetext{
5 To be pronounced fillo-xee-ra with emphasis of the xee, according to Hilgard. In a letter, December 30, 1880, he called the filloxara pronunciation "Barbarian." He based this on the Greek origin of the word-phyllon (leaf) and xeeros (withered) - and "that it sounds better."

${ }^{\circ}$ The discovery of phylloxera on August 19, 1873, was reported to the Sonoma Vinicultural Society on August 23, 1873, and is reviewed in the First Annual Report of the Board of the Viticultural Commissioners (1881).

7 The resistant stocks employed are usually native American species of $V$ itis or their hybrids. Unfortunately their fruit is quite unsatisfactory for wine. These are, therefore, planted as the rootstock and a scion of the desired variety of Vitis vinifera is grafted on.
} 
vineyard. In 1883 Hilgard seemed to change his mind about the value of $V$. californica as a rootstock. On February 8,1883 , he wrote that he would not use it; but a letter on January 14, 1884, indicates that he preferred it. This recommendation of $V$. californica was repeated in Bulletin $3(1884 a)$ and in Bulletins 34 (1885a), $45(1885 b), 46(1885 c)$, and $64(1887 b)$. In the last report he incorrectly blamed poor soil conditions for the reported failures. Furthermore, he used mainly $V$. californica in his own vineyard at Mission San Jose in 1884 and $1885 .{ }^{8}$ Hilgard's faith in this rootstock was based on the mistaken belief that a wild species would unquestionably be more resistant than a cultivated one.

At the conclusion of the Report of the Viticultural Work (1886a), Hilgard noted that the prominent French expert Millardet had reported $V$. californica to have no more resistance than $V$. labrusca, which is very low in resistance. Nevertheless, he still believed that experience in California justified planting this stock. At the Fifth Viticultural Convention (1887), when Estee, another vineyardist, made a good report on resistant stocks, Hilgard defended $V$. californica. It is apparent from the report that he was influenced more by temporary results than by any long-range experiments. In defense of Hilgard, C. A. Wetmore's advocacy of $V$. californica, made at the same convention, should be mentioned. Wetmore had been recommending and selling seeds of $V$. californica for several years.

The resistance of $V$. californica was discussed by Leonard Coates, of Napa, at the Sixth State Viticultural Convention (1888); Coates said that it "is not really resistant, except in some few instances. ..." Hilgard was asked a direct question as to the resistance of $V$. californica, but he did not reply, possibly because numerous questions on practical aspects of grafting had intervened. The sad fact is that $V$. californica at first was successful in noninfested vineyards and in moist soils. In California, phylloxera progressed slowly so that the supposed immunity of $V$. californica was not clearly disproven until the 1890 's. By 1900 Hilgard and many other vineyardists had lost part or all of their vineyards because of phylloxera infestation.

In the early 1880's most of the work at the University on phylloxera was done by Hilgard's assistant, F. W. Morse. Later, the Board of State Viticultural Commissioners seems to have been responsible for the work. After this Board was abolished, Hayne, an early viticulturist on Hilgard's staff, wrote in the Report of the Viticultural Work (1896) that the responsibility for phylloxera control had been under this Board "for the past fourteen years." Work on resistant stocks at the University was then renewed and several bulletins published.

\footnotetext{
${ }^{8}$ As early as December 5, 1879, Hilgard wrote to Kearney, an important Fresno vineyardist, that he believed the future of vine growing would be brilliant in California, and that if he had money he himself would invest in the industry. By June 18, 1883, he had purchased 25 acres at $\$ 80$ per acre, at Mission San Jose. He wrote Loughridge, later Professor of Agricultural Chemistry at Berkeley, on May 5, 1885, that he had been going to the vineyard nearly every other day to get his vines in. He called this the "Mission" vineyard. It was later expanded to 36 acres. It served as a summer home for the Hilgard family and for years kept Hilgard in debt. Hilgard was also associated with Juan Gallegos in the latter's wine company; he was apparently active in this company because, as late as 1887, when his argument with Wetmore was fierce, he wrote Doyle that he had been to Wetmore's office to buy Cabernet wine for the Gallegos Wine Company.
} 
Other proposed remedies were also investigated by Hilgard. In Bulletin 18 (1884c) he expressed guarded interest in J. A. Bauer's quicksilver remedy. A year later, after numerous tests, he reported negative results in the Viticultural Report of 1883-84 and 1884-85 (1886a), and in Bulletin 48 (1885d).

Defense of the University's vineyard also fell to Hilgard. The vineyard had been infested with phylloxera before Hilgard took it over; now Alameda vintners were petitioning the Regents to remove the vineyard, fearing that the aerial form of the insect might carry the disease over the Berkeley Hills to Livermore. Details of this controversy may be found in the Viticultural Report of 1883-84 and 1884-85 (1886a). Hilgard correctly maintained that no danger existed, and the Regents sustained him. The vineyard proved of great value in Morse's study of phylloxera.

Hilgard's great early contribution to the study of phylloxera was to focus attention on the danger, to clearly outline its complicated life history, and to recognize that resistant stocks offered the best remedy. He correctly noted that the winged form was not prevalent in California and that the disease spread slowly. In insisting that $V$. californica was a resistant stock, however, he erred. On July 12, 1903, he wrote to his sister Rosa that phylloxera had destroyed most of the vines in his own vineyard at Mission San Jose, "and we will have to sell it for its value as bare land, if we can."

\section{VARIETAL STUDIES}

Hilgard's interest in the wine industry of California appears to have been stimulated by the thirteenth exhibition of the Mechanies' Institute of San Francisco which was held in San Francisco in 1878. Hilgard served as a member of the tasting committee, and commented on the results in his Biennial Report (1879). He particularly noted that California's warm climate led to the development of excessive sugar in the grapes and hence of alcohol in the wines, particularly in those made from the Mission grape. Obviously, experiments had to be made on intelligent blending of different varieties of wines from various regions.

On February 14, 1879, Hilgard wrote to his sister Rosa that he had been to Sacramento at the invitation of the Wine Committee of the Assembly, and that he hoped to obtain $\$ 4,000$ for viticultural work at the University. On April 3, 1880, in a letter to S. G. Nye, a state senator at Sacramento, he supported the proposed viticulture bill then before the legislature. Again he emphasized that viticulturists had not sufficiently reckoned with the influence of the warm climatic conditions of California on grape maturity, and that the prevalent wine-making practices were not suitable for our grapes. Systematic and scientific investigation, he believed, was necessary to provide better viticultural and enological procedures. Questions about soils and the utility of foothills for vineyards, for example, remained to be answered. He ended: "And with all this they [the growers] need to know, and that quickly, which of the 2,500 grape varieties they shall choose for this purpose [that is, for the improvement of California wines]." Here was the beginning and the heart of Hilgard's viticultural work.

The law, passed on April 15, 1880, consisted of two parts: one, the creation 
of a Board of State Viticultural Commissioners; and two, the delegating of certain duties related to instruction and research in viticulture to the University of California. Significantly, the act made an annual provision of $\$ 3,000$ for this work, and further authorized the Regents of the University to accept donations of land for experimental vineyards.

In his report to the Regents for 1880 (1881), Hilgard notes that funds were not made available until August of that year. But by October 10, a $20 \times 46$ foot cellar had been constructed near South Hall on the Berkeley campus, and some fourteen experimental fermentations were completed that season. Plans for this work, clearly stated in the report, were reprinted with few changes in several later reports:

The plan adopted in this matter is in conformity with my view, expressed in my previous report, ${ }^{\circ}$ and shared by the best vintners in the State, viz.: that among the first necessities of the present situation of California wines in the world's market, is the establishment of more definite qualities and brands, resulting from a definite knowledge of the qualities of each of the prominent grape varieties, and of their influence upon the kind and quality of the wine, in blending before, or as the case may be, after fermentation; of the treatment required by each in the cellar, during the time of ripening; and finally, of the differences caused by difference of location, climate, etc., as well as by different treatment of the vines themselves.

Hilgard apparently realized the breadth of this program, as well as the fact that it was the only one likely to yield early and important results. This remarkable project has the insight and comprehensiveness of a modern scientific agricultural project. For its time it was extraordinary.

In 1880, two varieties dominated California vineyards: Mission, an old variety, highly productive but utterly worthless for table wine production; and Zinfandel, a variety of good color and acidity but often characterized by excessive sugar and, frequently, susceptibility to considerable bunch rot. Further, it was adapted primarily to limited foothill areas in the cooler regions.

At first Hilgard tried to produce a red and white wine from each red grape variety, but this merely increased the labor without developing better wines. Later, red wines were made from red grapes only, and white wines from white grapes only. About 7 gallons of each lot were usually produced. The grape juice was analyzed and, after fermentation, the wines were also analyzed and critically tasted. Among the grapes received in 1880 were Zinfandel, Malvoisie and Burger from the pioneer Napa Valley vineyardist, Charles Krug, of St. Helena; and Pinot noir from General Naglee of San Jose. (In his report to the Regents for 1882, Hilgard identifies the latter variety as Charbono, instead of Pinot noir. Misnaming of grape varieties has been a persistent problem of California viticulturists.)

In the report of 1882 (1883) only about fifteen samples of the vintage of 1881 were fermented. Well-known growers, like Gundlach, of Sonoma, and

\footnotetext{
${ }^{\circ}$ I have been unable to locate any previous printed report where such a definite program for the viticultural studies is outlined.
} 
George West, of Stockton, sent grapes, but the varieties, such as Lenoir, Mataro, Feher Szagos and Black Prince, were not outstanding. In addition to the wines produced at Berkeley, wine samples sent by many growers for analyses were reported on in detail. This feature lasted several years but was of gradually decreasing importance. Wine producers cooperating in the study were among the most prominent in the state: I. De Turk, George Husmann, H. W. Crabb, Dressel \& Co., Charles Le Franc, B. Dreyfus \& Co., J. De Barth Shorb, T. F. Eisen and J. T. Doyle. The report also includes a lengthy discussion of the ash content of the various varieties from different regions, probably a reflection of Hilgard's interest in soils.

In 1882 no wines were produced (see Viticultural Report of 1883-84 and 1884-85, 1886a). But in 1883 work was continued, and 18 lots fermented. In 1884 the work was greatly expanded, 67 lots being produced. Of these, 44 were from the extensive variety collection of the Natoma Water and Mining Company near Folsom. Hilgard's assistants at this time were M. E. Jaffa, the Pohndorffs (father and son), and George Colby.

The Viticultural Report for 1883-84 adopted a new system of classifying the many varieties of grapes tested. This system, an artificial grouping based on the country or district of origin, was retained until the last (1896) report. Thus, grapes were classified, among others, as Bordeaux type, Burgundy type, Southern French and Italian type, American type, and Rhenish type. Extensive ampelographical notes were included for each of these; notes which Hilgard acknowledged were based on the work of Mas and Pulliat. ${ }^{10}$ Despite its title, the Viticultural Report for 1883-84 and 1884-85 does not include grapes of the vintage of 1885 .

In the report for 1885-86 (1886b), Hilgard notes that about 40 lots were fermented in 1885, in addition to about the same number of must analyses. In 1886, new facilities became available and over 100 lots were handled. The detailed comments on the cultural characteristics of each variety were continued in this report. Some difficult points of varietal identification are noted, and there is a wealth of detailed viticultural information. This example of his description is a good one:

The Fresa [now usually spelled Fresia] is the companion of the Barbera in the vineyards of Piedmont, and especially in the neighborhood of Turin and Monferrate. It is not generally esteemed as yielding wines of as high quality as the Barbera, but yet those from certain localities enjoy an excellent reputation. These differences are probably due to the nature of the soils and exposure. The vine is vigorous and productive, and in good soils attains an age of sixty and even a hundred years; its life is prolonged by shorter pruning than is generally given it. It is especially esteemed for its resistance to the mildew.

The Fresa at Cupertino, bearing the second year from the graft, shors its productiveness very strikingly, the average of each of 7 vines being 28.5 pounds. The berries were, however, almost through-

${ }^{10}$ Undoubtedly from their three-volume work Le Vignoble published in Paris between 1874 and 1879. 
out, smaller than those of the figure of the 'Vignoble,' although in other respects it agrees exactly with the description. The color of its wines, though not quite as deep as that of the Barbera, is very strong and fine.

Up to this time, one of the disadvantages of the work had been the fact that, except for a few privately owned varietal collections, Hilgard was not able to get sufficient grapes from the various regions. With the passage of the Hatch Experiment Station Act by Congress in 1887 and a similar act by the State Legislature at about the same time, funds became available for establishing subexperiment stations on University-controlled property. During 1887 and 1888, Hilgard was much in demand by local enthusiasts who wanted a subexperiment station established on their property. Stations at Paso Robles, Tulare, and Jackson, in Amador County, were then established, and collections of grape varieties planted on them. ${ }^{11}$ Grapes from these were used in later years for the Berkeley varietal studies.

A brief report on methods of fermentation (1888) was followed by a detailed study on the vintages of 1887-89 with data on the vintage of 1890 (1892). This lengthy report, dealing mainly with red wine grapes, was prepared by Paparelli under Hilgard's direction. The final report of the viticultural work (1896) included the vintage of 1894. These last two reports may be considered to constitute Hilgard's important contribution to California viticulture since they summarize most of the results which he obtained.

These reports may be summarized as follows: samples of grapes from the more important regions of the state had been brought to Berkeley, crushed, analyzed, fermented and the wines tasted and analyzed. For each variety a clear viticultural summary was published, giving information on its source, ampelographical points, and what could be expected from the variety under various conditions. A beginning was made in the classification of the many varieties of wine grapes based on the qualities of their wines. Hilgard himself wrote in the 1896 report, "I am convinced that, with the proper understanding and utilization of the data given in this report much of the uncertainty and haphazard heretofore prevailing will disappear, and that both in the selection of the grape-varieties to be planted, and of the proper blends to be made for particular purposes and types, the data imparted by analyses and the records of vinification will be found of the greatest practical use."

These reports could not have failed to be of the greatest interest and utility to California vineyardists. The high quality of the varietal plantings in the vineyards of California at the time of Prohibition undoubtedly owed much to Hilgard's efforts. Why then, did the work of Hilgard fail to have a significant influence on post-Prohibition vineyards and vintners? The main reason was that during Prohibition, many of the finest vineyards were uprooted and replanted, either with table grapes or with wine grapes that would withstand injury during shipment to the East Coast. Furthermore, the wine makers who were quality conscious prior to Prohibition had largely left the industry at the time of Repeal. At the expense of quality, many post-Repeal producers

\footnotetext{
${ }^{11}$ A good description of each of these stations and of the Berkeley station may be found in the Report on the Agricultural Experiment Station for 1888 and 1889 (1890a).
} 
have largely stressed quantity and low production costs. Interest in the finer varieties of grapes has, therefore, been too limited, with some notable exceptions.

\section{MISCELLANEOUS VITICULTURAL ACTIVITIES}

Not only did Hilgard publish the 1,250 pages of formal Viticultural Reports, but he started a bulletin series in 1884. Many of these early bulletins were progress reports on the work of the viticultural laboratory and were intended for republication in daily and weekly newspapers throughout the state. Most of this material eventually found its way into the Experiment Station reports. (See the Appendix for a list of bulletins.)

Hilgard did not hesitate long to apply his knowledge of soil science to California viticulture. His talk at St. Helena (1880) on "The Permanent Maintenance of Our Vineyards" was published in the first annual report of the Board of State Viticultural Commissioners. His most pertinent recommendation was that the pomace from the winery be placed on the vineyard. The recommendations concerning the use of lime, potash, and phosphates for vineyards were, perhaps, based too much on his Mississippi experience to be of real significance in California.

Discussing the failure of Muscat grapes in certain southern California areas (Bulletin 17, 1884b), Hilgard recommended fertilizer trials. Later in Bulletins 24 and $25(1884 d ; 1884 e)$ he reported on the results of analyses of vineyard soils in several counties.

Hilgard also gave detailed advice to viticulturalists all over the state concerning vineyards and varieties, as well as rootstocks, grafting, and combating phylloxera.

Not all of his work was accomplished smoothly. From 1884 until 1894, Hilgard carried on a running battle with C. A. Wetmore, an executive of the Board of State Viticultural Commissioners.

Following the establishment of the Board of State Viticultural Commissioners, and the viticultural activities at the University, the two groups set out at once on separate paths. Hilgard regretted this and even proposed a cooperative effort and division of labor in a letter to Wetmore on January 5 , 1885.

Wetmore apparently mistrusted Hilgard's frank statements on the quality of California wines and never visited the Berkeley laboratory. Wetmore's lack of cooperation led Hilgard to write (March, 1885) "... hoping that some one will hunt up in Webster's Dictionary for Mr. Wetmore the English meaning of the word cooperation...."

Arpad Haraszthy, C. A. Wetmore, and the other leaders of the Board, prided themselves on being "practical." Their attitude is expressed in this statement by Wetmore (Third State Viticultural Convention, 1884):

The young gentlemen who conduct the experiments of the University are able young men but they are not old practical men. What we suggest is that you should begin as I have this year, from the beginning, and claim that there are brains and talent enough in the State to give you all the information you want, and if you think 
there is any difficulty in the matter of making wine then you must think I am a wonderful man and my wife a wonderful woman, for we have made good wine in a cowshed. I do not believe this business should be mystified with the idea that it requires great erudition to begin with.

In his report of May 9, 1885, to the Viticultural Commissioners, Hilgard offered a telling rebuttal (quoted in 1886a):

It has been said, by way of comfort to beginners, that wine-making is, after all, an easy thing, which can be done by any one with a few casks and a little common sense. It is quite true that something that will pass for wine, for awhile at least, can be so made, and also that, where a certain practice with certain materials has long been established, any one can make good wine by following exactly the established rule-of-thumb. But no such state of things exists in California, and it is not safe to persuade the public that it will take no more than the above outfit to make wines that will find profitable sale, from the indefinite materials found in our vineyards. More than this, it is not well to allow the inexperienced wine-maker to make, on 'common-sense' principles, wine that will bring him fifteen cents per gallon, when, if properly instructed, he might have obtained double that price.

The controversy arose following the Third Annual Viticultural Convention of December, 1884 (1884), at which Hilgard had submitted a large number of experimental samples to the tasting committee. Hilgard himself was a member of the committee. Samples produced by the Viticultural Commission were also submitted for tasting. So impressed was the convention by Hilgard's accomplishments that a committee of five was appointed to investigate and report on the University's viticultural laboratory. It is important to remember that this resolution was specifically directed toward the University's work and its expansion. The report deplored the lack of space at Berkeley and requested the legislature to appropriate $\$ 10,000$ for a suitable viticultural laboratory "in connection with the Department of Agriculture of the University of California, to be operated under the charge of the Professor of the said Department of Agriculture." Wetmore cautiously supported this resolution.

Hilgard and Wetmore expressed their antagonism in several verbal exchanges during the convention. Hilgard advocated larger wineries under trained wine makers. Wetmore believed that fine wines would be made only in small wineries, and that anyone could make fine wine. Here the difficulty appears to be that while the average quality would have been greatly improved by Hilgard's method, high quality would not be assured. On his part, Wetmore did not take into account the gross ignorance of many proprietors of small vineyards and wineries.

The two men also disagreed violently on the use of yeast cultures. Hilgard, who deplored the use of all yeast cultures, was undoubtedly wrong. But Wetmore was no more correct in the type of yeast recommended. Not until 
1893 were studies on yeasts instituted at Berkeley, and by that time pure yeast cultures were already being used by the industry. When Hilgard announced the start of the yeast studies, the Pacific Wine and Spirit Review (which usually reflected Wetmore's views) caustically remarked on June 20,1893 , that the studies were "about two years late" (Anonymous, 1893).

And finally, Hilgard and Wetmore were opposed on the amount of alcohol which table wines should contain. Hilgard, in arguing for a lower percentage of alcohol in California table wines was, in our opinion, correct, though many California wines still reflect Wetmore's point of view.

The resolution of the Viticultural Convention of 1884 was approved by the legislature in 1885 , but the appropriation was placed under the joint control of the Regents and the Board of State Viticultural Commissioners. This action was the result of some behind-the-scenes work of Wetmore, which Hilgard outlined in a letter to J. T. Doyle, a prominent lawyer and a vineyard owner at Cupertino (February 17, 1885). "His coup d'etat was managed as astutely as could have been done by Metternich himself." A joint committee of the Regents and the Commissioners met in the spring of 1885, and failed to come to any agreement as to the joint control.

The Commissioners and Hilgard then submitted letters to the Regents outlining their diverse views. Wetmore proposed a dual control and wanted to place the cellar in San Francisco. Hilgard was furious. The extra money had been secured on the basis of his work; the laboratory formed a natural part of the work of the College of Agriculture; and the cellar could not receive the same supervision in San Francisco as in Berkeley. The Regents quickly agreed with Hilgard. Hilgard raised the further valid objection that he could not place his work in the hands of amateurs. At the 1884 Viticultural Convention, Wetmore and Wheeler, a Livermore vineyardist, had both admitted that neither had made wines prior to 1883 .

This controversy did not end until March, 1886, when the Regents and the Board of Viticultural Commissioners split the $\$ 10,000$. Looking back on the polemic, one wonders what Wetmore hoped to accomplish by dueling with Hilgard.

As soon as Hilgard recognized his enemy, he spared no pains in protecting his own work. On March 11, 1886, he suggested to J. B. J. Portal, San Jose vineyardist, that a state viticultural society, which Wetmore could not control, might be formed. He also submitted samples of experimental wines to this convention and he was able to write (April 9,1886) that the convention passed fairly pleasantly. When Wetmore resigned as an official of the Board of State Viticultural Commissioners in January, 1887, Hilgard noted that when you give men like Wetmore "rope enough ... they will hang themselves." Hilgard foresaw the end in a letter to Professor R. H. Loughridge (January 17, 1887), in which he noted Wetmore's defeat on his "Green Spurious Wine Bill," as well as the legislature's growing tendency to eliminate special commissions, concentrating their activities in the University.

But Wetmore was not through. He emasculated the "Pure Wine Bill." Wetmore's forensic abilities are indicated by the remarks attributed to him in a letter of Hilgard's to A. P. Hall on February 4, 1887, "Anybody can make good wine-no need of large and expensive wineries-a cow-shed will 
do-or even the shade of one of our grand old oaks." On April 16, 1886, Hilgard had written to William Pfeffer, a prominent Santa Clara County vineyardist, "Let us give Wetmore credit for what he is good for-energy, aggressiveness and inexhaustible cheek; all of which have their uses." But the report on the University samples submitted to the Fifth Annual Convention in March, 1887, was decidedly unfavorable (1887). Hilgard wrote Pohndorff on April 18, 1887, that Wetmore heaped insults on him and refused to cooperate.

The Sixth Annual Viticultural Convention in March, 1888, passed pleasantly, but on April 16, 1890, Hilgard wrote to his brother Julius and the latter's wife, "My old enemy Wetmore has organized a newspaper campaign against me." This was apparently in retaliation for Hilgard's famous letter to the San Franciseo Examiner on August 8, 1889.

In 1895 the Board of State Viticultural Commissioners was finally abolished, and its functions and records turned over to the College of Agriculture of the University. But the strain continued. Even as late as June 9, 1904, Hilgard observed in a letter to C. H. Shinn, earlier a Commissioner on the State Board of Viticultural Commissioners, that Wetmore had tried to seize control of the newly organized Viticultural Club. But he was no longer so bitter; he referred to his "old enemy" as "Charley Wetmore."

It is clear that a fundamental difference of opinion existed between Hilgard, the scientist, and Wetmore, the publicist. Significantly the public recognized who was right. It is the quality of the wine which counts. Modern apologists for the California wine industry would do well to ponder this lesson.

\section{FERMENTATION AND OTHER ENOLOGICAL STUDIES}

Although Hilgard devoted the major portion of his attention to varietal studies, he also made significant contributions to wine-production problems.

First, he insisted on cool fermentations. In the Viticultural Reports for 1883-84 and 1884-85 (1886a), Hilgard recommended temperatures between $40^{\circ}$ and $62^{\circ} \mathrm{F}$ for producing white table wines, and he correctly noted the differences in quality between wines fermented at these low temperatures and at higher ones. He particularly blamed high temperature fermentation for the prevalence of lactic acid bacterial spoilage of new wines. Even today his statement that "measures for keeping the temperature of fermentation within lower limits are among the most pressing needs of our wine-making industry" can hardly be overemphasized. While many California wineries now have cooling equipment, there are still some which do not recognize the importance of temperature control, and the quality of their wines suffers accordingly. Hilgard also discussed the question of fermentation temperature at the Third Annual Viticultural Convention (1884). Unfortunately, Wetmore so vehemently decried the necessity of controlling temperature during fermentation that Hilgard's recommendations were probably less effective than they should have been.

In his report a year later to the Viticultural Commission, Hilgard again stressed excessive rise of temperature during fermentation as one of the three principal causes of the poor quality of California wines. 
The other two were "want of care in respect to the exclusion of unsound grapes from the crushing process," and "undue access of air [during and after fermentation], allowing partial acetification." As the vintners came to recognize the truth of these sound observations, the quality of California wines markedly improved.

Early in his viticultural work Hilgard conducted an extensive investigation on methods of fermenting red wines. This work was reported in Bulletins 63,68 , and $77(1887 a ; 1887 d ; 1887 e)$, and in the Advance Sheets for the 1887 Viticultural Report (1888). The main experiment in 1886 was a series of nine Zinfandel fermentations, fermented at different temperatures and using different methods of handling the cap. These were the methods then in use or being recommended: submerged cap, three lattice frames in the fermenters, floating cover on the fermenter, crushing whole grapes by stirring (Morel process), cap not punched, and cap punched three times per day.

These studies were repeated in 1887 with Carignane, at which time some changes in procedure were followed. This study furnished proof that color extraction was completed prior to the end of fermentation. This useful result was new at that time but is commonly known today except by the less wellinformed vintners. Other results reported were the inferiority of the Morel process and the fact that submerged caps were satisfactory if the cap was well submerged. Vintners were cautioned against stirring the cap with air. The report stated further that hot fermentations failed to increase the color permanently but did increase the tannin content.

The influence of temperature on the tint of the wines is not as clear as Hilgard believed. In Bulletin 60 (1886d), Hilgard had introduced the Vino Colorimeter, which he used extensively. Since this is not a precision instrument, further work would be required to establish the influence of temperature on the color characteristics of wines. He was probably correct, however, in stressing the fact that hot fermentations tend to yield wines with a port character, and cool fermentations, wines with a claret character. His observation that aeration reduced the tannin content of red wines is correct. Undoubtedly the formation of aldehyde-tannin complexes is responsible for this effect.

The relatively new process of wine pasteurization early met with Hilgard's approval, and at the Fifth Viticultural Convention (1887), he discussed the process at length. Bulletins $66(1887 c)$ and 87 (1890b) also contain a discussion of the principles and practice of pasteurization. Hilgard was correct in stressing the need for pasteurization out of contact with the air. He also emphasized that the process did not confer on the wine any immunity from reinfection. Both these points have been too frequently neglected by wine makers.

Hilgard's interest in condensed grape juice dates from about 1877. In his report to the president of the University (1877), Hilgard discusses a sample of grape syrup sent to him for examination, and gives advice on preventing solidification. He recommended less neutralization of the acidity prior to concentration.

At the Sixth State Viticultural Convention (1888) he brought samples of grape concentrates and of fermented wines made from them. The wines were reported to have fermented satisfactorily, although Arpad Haraszthy, 
son of Agostin and a prominent viticulturalist and wine maker himself, reminded Hilgard that he had had lactic fermentations of such diluted musts. Haraszthy's observation appears to be correct for those cases where sulfur dioxide is not used prior to fermentation. In 1888, sulfur dioxide was not commonly used in this connection. Interest in concentrate was stimulated by the potential export market as well as its possible use for sweetening dessert wines. A number of installations producing concentrate were in operation at this time. Bulletin 54 (1886c) dealt with condensed grape must and its uses. The samples produced by vacuum concentration reported therein may have been the first so produced in the state.

Hilgard held strong ideas on temperance. A moderate drinker himself, he abhorred drunkenness. For his persistent throat problem he took a tablespoon of brandy and some cream following his lectures. ${ }^{12}$ In 1878 , he wrote that he had given up his bottle of beer per day and had started drinking a Zinfandel wine as his table beverage_-"moderately strong and strictly pure." In 1886 he wrote that he was using Schram's burgundy (usually made from the Refosco variety) at meals.

It is possible that his personal animosity toward Wetmore was based, in part, on the latter's predilection for spirits. (See letter to C. H. Shinn, June 9,1904 .) Basically, he said, the fault is not in the beverage but in the men and women who drink it.

More original was his recommendation that cooking schools be established. He believed that if the standard of our cuisine was raised, more wines would be drunk with meals and temperance fostered. The abolition of nine tenths of the saloons by raising their taxes to crushing levels, he considered the most direct means for the repression of the evils of drunkenness. He once wrote Wetmore (November 23, 1884) that opponents of temperance fanatics should act more temperately than the fanatics. At this time Hilgard was keenly interested in temperance, because he and Wetmore had clashed at the Viticultural Convention (1884) on the subject. He wrote to Pohndorff (December 10, 1884) that wines of 15 per cent alcohol were not a temperance beverage; that you couldn't cure drunkenness by putting hot wines on people's tables; and that cheap, bad brandy was no better than whisky.

Probably Hilgard's greatest contribution to the California wine industry was his insistence on quality. Year in and year out, he preached quality, no matter how much the industry winced. At the Third Viticultural Convention (1884) he said:

It will not do for us to say that because a bottle of Mission wine is 16 years old, that therefore we must go into ecstasies over it. I recollect a gentleman becoming very enthusiastic over a bottle of 16-year-old Mission wine, and dared me to say that it was not the best wine I ever drank. But I did dare to say that it was no better than the second year that [it] came out of his cellar. He thought me very unpatriotic and that I ought to have said something different, but this mutual admiration society business will not help us in the world's market.

${ }^{13}$ In a letter to General Naglee of San Jose, a pioneer in the production of good brandy in California, Hilgard wrote (April 14, 1878) that brandy should be distilled from wine. Another letter on April 17, 1880, praised the quality of Naglee's brandy. 
The goal of his viticultural work was the improving of quality. In the fight with Wetmore, on the Pure Wine Bill in 1887, his main concern was to prevent adulteration with such additions as cider or elderberries.

When he gave a frank and unfavorable opinion of Barton' $\mathrm{s}^{13}$ wines, Barton rebuked him. Hilgard's reply (February 10, 1855) was elegant and to the point:

Yours of 8th is rec'd. From the tenor of your last two letters, I apprehend that no candid estimate of your products will be satisfactory to you unless it is favorable. I was not aware that California claimed, so far, to have produced anything save perhaps a few samples in the way of what is commercially and oenologically known as 'first-class' wines. I certainly have not seen them, and will be pleased if I myself, during the first years of my experience, produce anything above a good second class wine from any grape in my vineyard. As to the experts who have pronounced your Eukger 'first-class,' I hope you will be able to make that opinion govern the prices at which you sell it. If you desired no discussion of your products save a favorable one, it was a mistake to send them to me, as the object of my work is to learn how to produce wines that will hold an honorable place, under their own name, anywhere in the world. If you are satisfied that you have nothing more to learn, you stand alone in California. Certainly neither Wetmore, nor Pohndorff, nor I have any such ideas as to ourselves.

As to the intimation that I serve as the mouthpiece of the two gentlemen just mentioned, in what I publicly state as my opinion and the result of my experiments, I have no answer to make. Probably you did not mean to be offensive, but I trust that any future communications will be more guarded in this respect.

But Hilgard's biggest blow for quality was struck in 1889, when the industry was in the throes of one of its periodical depressions. ${ }^{14}$ William Randolph Hearst had published in the San Francisco Examiner an open letter to viticulturalists throughout the state inviting letters suggesting ways to alleviate the depression. Many letters were published. The depression was blamed on excessive production of grapes, the chicanery of the wine merchants, poor distribution of our wines at home and abroad, competition of cheap imported wines, lack of advertising, and numerous other causes. Hilgard's reply was published on August 8, 1889, in the San Francisco Examiner. It covered two columns and stated his position clearly. In answer to the question "What do you consider the cause of the present depression in the wine market?" he wrote: "Chiefly and fundamentally the poor quality of the larger part of the wines made, and their immaturity when put on the market.... It is high time that the ostrich-like policy of hiding the faults of our wine-making from ourselves were done away with once for all."

\footnotetext{
${ }^{18}$ Berton was a prominent Fresno viticulturist and wine maker.

${ }^{14}$ In his article, "The Future of Grape-Growing in California" (1884f), Hilgard blamed the depression in wine prices of 1875 on the poor quality of California wines and predicted another depression if the quality of our wines did not improve. The low prices for grapes and wines in 1889 thus confirmed, partially at least, his prediction.
} 
He then went on to outline how California wines could be improved. First, the wine makers should either learn how to make sound wine or abandon their occupation. Reprehensible practices which he noted as being prevalent were: (1) growing excessive crops on valley lands, (2) attempting to handle such a large acreage that each variety is not harvested at the proper time, (3) carelessness in picking, so that moldy, sunburned or rotten grapes are not excluded, (4) filling the fermentation tanks too high so that there is no space for a protective cover of carbon dioxide, (5) using excessively large fermenting tanks and hot grapes, (6) stirring up a spoiled cap, (7) leaving the wine too long on the pomace, (8) storing the wines in a cold place too soon and thus preventing the secondary fermentation, (9) defective aftertreatment of the wine, such as using tanks which are too large, failure to rack often enough, and not excluding air during racking, and (10) selection of varieties unsuited to the local climate.

Modern techniques have eliminated many of these poor practices, but all are still sometimes operative in reducing the quality of our wines. Hilgard's statement that "poor wines, from whatever cause produced, must be consigned to the still, instead of being thrown upon the market at any price" has much to commend it. Hilgard concluded: "It takes but a few consignments of poor stuff to tarnish the reputation of the whole State, and to inflict heavy pecuniary loss upon thousands of innocent [grape] producers."

\section{HILGARD'S CONTRIBUTION}

In the post-Repeal California grape and wine industry the name of Eugene Waldemar Hilgard is practically unknown. Is this because he made no lasting contributions to our industry? Or is it simply that his work is unknown? Or because of other factors?

We can dismiss at once any charge that his work lacked permanent value. Hilgard recognized that the unique climatic characteristics of California would have a profound influence on the grape and wine industry. As a result of his research, he made lasting contributions to our knowledge of the response of many varieties to California conditions.

Prohibition cut the wine industry completely off from its historical background. There is good reason to believe that Hilgard's work was well known in the 1880's and 1890's. Miss Wait (1889), for example, quoted Hilgard's work and praised it. The men and companies that flourished during this period were almost all gone or replaced by new owners in 1933. Lack of knowledge of Hilgard's work certainly accounts in large part for the present wine industry's lack of appreciation of it.

Perhaps there were other factors which reduced the impact of Hilgard's research. He was a proud and opinionated man. His controversy with Wetmore was unfortunate and weakened him in the eyes of the industry. However, the industry was sometimes unfair. The phylloxera controversy, for example, was exaggerated out of all proportion to its importance. The industry was shortsighted in not heeding Hilgard's recommendations for improving the quality of California wines.

Today we can recognize Hilgard as one who began the systematization of 
viticultural knowledge in California. The opinions and theories of those in the industry who disagreed with him have largely disappeared. Hilgard's research, on the other hand, is on the record and is generally still sound and practicable.

\section{LITERATURE CITED}

\section{Anonymous}

1893. About two years late. Pacific Wine and Spirit Review 30(10):18.

California Board of Viticultural Commissioners

1881. First annual report. Edward Bosqui \& Co., San Francisco.

California State Viticultural Convention

1884. Third Annual Convention. (See Appendix, number 58.)

1887. Fifth Annual Convention. (See Appendix, number 60.)

1888. Sixth Annual Convention. (See Appendix, number 61.)

Hilgard, E. W.

1860. (See Appendix, number 48.)

1876. (See Appendix, number 50.)

1877. (See Appendix, number 51.)

1879. (See Appendix, number 52.)

1880. (See Appendix, number 54.)

1881. (See Appendix, number 55.)

1883. (See Appendix, number 57.)

1884a. (See Appendix, number 1.)

1884b. (See Appendix, number 6.)

1884c. (See Appendix, number 7.)

1884d. (See Appendix, number 10.)

1884e. (See Appendix, number 11.)

1884f. (See Appendix, number 60.)

1885a. (See Appendix, number 13.)

1885b. (See Appendix, number 20.)

1885c. (See Appendix, number 21.)

1885d. (See Appendix, number 22.)

1886a. (See Appendix, number 43.)

1886b. (See Appendix, number 44.)

1886c. (See Appendix, number 24.)

1886d. (See Appendix, number 25.)

1887a. (See Appendix, number 29.)

1887b. (See Appendix, number 30.)

1887c. (See Appendix, number 32.)

1887d. (See Appendix, number 34.)

1887e. (See Appendix, number 39.)

1888. (See Appendix, number 45.)

1889. (See Appendix, number 63.)

1890a. (See Appendix, number 64.)

1890b. (See Appendix, number 40.)

1892. (See Appendix, number 46.)

1896. (See Appendix, number 47.)

JENNY, H.

1961. E. W. Hilgard and the birth of modern soil science. Collana della Rivista "Agrochimica," Pisa. 144 p.

Johnson, A. J.

1876-78. (See Appendix, number 49.)

WAIT, F. E.

1889. Wines and vines of California or a treatise on the ethics of wine drinking. The Bancroft Company, San Francisco. 215 p. 


\title{
APPENDIX
}

\section{A BIBLIOGRAPHY OF HILGARD'S PUBLISHED WORKS ON VITICULTURE}

\author{
A. University of California, College of Agriculture, Agricultural Experiment Station \\ Bulletins
}

1. [Remedies for phylloxera.] Bull. 3, 2 p. 1884.

Reviews some proposed control measures, recommending resistant stocks for new vineyards that cannot be flooded. Notes occasional difficulty in rooting cuttings.

2. Comparative examination of claret grapes from Fresno and Livermore Valley. Bull. 6, 2 p. 1884.

A comparison of the musts and wines of Grenache, Mataro, and Carignane from Fresno and Livermore correctly showing the higher alcoholic content and lower acidity of the former.

3. Examination of Zinfandel wines. Bull. 9, 3 p. 1884.

Analysis of wines from San Diego to Santa Rosa with recommendations for blending, which Hilgard considers necessary. It is difficult to understand how three white wines were made from Zinfandel grapes since nowadays Zinfandel juice is usually pink as it comes from the erusher.

4. Examination of Zinfandel wines. Bull. 12, 2 p. 1884.

A supplement to the previous bulletin. Hilgard makes the point here that a grape which is satisfactory for blending at Livermore may not be satisfactory at Napa or Fresno.

5. Examinations of red or claret wines from Mr. H. W. Crabb, Oakville, Napa County. Bull. 13, 2 p. 1884.

Analyses of several varieties of wines. Crabb's Black Burgundy is considered to have the best chemical composition for claret. Hilgard's emphasis in all these early bulletins was strictly on the chemical analyses of wines, though he notes in passing the importance of tasting.

6. The Muscat grape on the southern mesas. Bull. 17, 2 p. 1884 ?

Hilgard doesn't think failure of Muscat grapes on these soils is due to lack of moisture. He recommends fertilizer trials.

7. Mr. J. A. Bauer's phylloxera remedy. Bull. 18, 2 p. 1884.

Bauer's remedy was the introduction of finely divided quicksilver into the soil. Hilgard expresses interest but still thinks resistant stocks a better remedy.

8. Examination of red wines from Sonoma and Napa Counties. Bull. 21, 2 p. 1884.

While not signed by Hilgard nor listed in the University Archives as being his, there seems no doubt that Hilgard wrote this bulletin. The style is his and it follows his previous work on the composition of wines. Hilgard here stated that if sugar or alcoholic content were the only criterion used in buying grapes or wines, there would be no hope of improving "the quality and reputation of California wines by the introduction and culture of the best grape varieties."

9. Vintage work in the viticultural laboratory, 1884. Bull. 23, 2 p. 1884.

Hilgard defends the use of small cooperage; notes that eighty-six samples were fermented; and hopes for a larger legislative appropriation.

10. Examinations of grape-growing soils. Bull. 24, 2 p. 1884 ?

Analyses of Fresno and Napa soils.

11. Examinations of Alameda County vineyard soils. Bull. 25, 3 p. 1884 ?

Although not dated or signed, this is obviously a continuation of the previous bulletin. Livermore and Mission San Jose soils are analyzed.

12. Examination of Trousseau and Burger wines. Bull. 31, 2 p. 1885.

Here Hilgard advances the theory that the lack of tannin in Zinfandel wines gives them their unpleasant acidity. Here again he is attempting to recommend blends on the basis of chemical analyses. Burger is approved of as a second- or third-class wine. 
13. Experiments on the growth of cuttings from wild American vines. Bull. 34, 2 p. 1885.

Vitis californica gets the lion's share of the praise as a resistant stock. Hilgard states that the stock affects the ripening time of the scion fruit.

14. Investigations of wines from rare grape varieties. Bull. 35, 3 p. 1885.

15. Bull. 37, 3 p. 1885.

16. Bull. 38, 3 p. 1885.

These three bulletins all have the same title. They deal with new varieties from the Natoma Water and Mining Company at Folsom, California. Mondeuse, Petite Sirah, Cinsaut, Petite Bouschet, Verdot, Merlot, Beclan, Cabernet franc and Cabernet Sauvignon are discussed. Less attention is given to analyses and more to tasting in Bulletin 38. Hilgard records a number of his own tasting results.

17. Clairette blanche. Bull. 40, 3 p. 1885.

This is really a continuation of Bulletins 35,37 and 38. Results of tests on Clairette blanche, Roussanne, and Marsanne are reported. The Clairette was considered best.

18. Vintage work in the viticultural laboratory, 1885. Bull. 42, 3 p. 1885.

Reviews the objectives of Hilgard's viticultural work and invites growers to send samples of 100 or preferably 200 pounds.

19. Analyses of Santa Clara Valley red wines. Bull. 43, 3 p. 1885.

A review of the analyses of wines from this region. Again Hilgard is concerned with blends for Zinfandel. He was looking for a high-acid, low-body wine.

20. Grafting the California wild vine. Bull. 45, 2 p. 1885 .

Defends $V$ itis californica's grafting ability and its resistance.

21. Grafting and fruiting of resistant vines. Bull. 46, 2 p. 1885.

Agrees with Husmann that Lenoir and other stocks are useful.

22. Investigations upon the mercurial phylloxera remedy. Bull. 48, 3 p. 1885.

Bauer's remedy (Bulletin 18), which was tested by Hilgard and others, failed. Investigation revealed that Bauer's mixture was contaminated with lead and oil and that heavier soils slowed down the movement of mercury vapor. Raising the temperature, however, made the remedy effective even in heavy soils.

23. The wines of 1885 . Bull. 51, 3 p. 1886.

The state of the California industry on this date is revealed by the fact that nearly half the samples of new wines sent in for analyses contained unfermented sugar. Hilgard notes the high acid and high sugar in the 1885 vintage-surely an anomalous result. The lime-sulfur spray for mildew on grapes is also discussed.

24. Condensed grape must and its uses. Bull. 54, 3 p. 1886.

Report of successful fermentation of samples of what may have been the first vacuum-pan concentrates produced in the state.

25. Vintage work and instruction in the viticultural laboratory, 1886. Bull. 57, 3 p. 1886.

Again Hilgard reviews his objectives, and gives advice to prospective students and to those wishing to submit samples of brandy, grapes or wine.

26. [The experimental vineyard-plot at Cupertino.] Bull. 59, 3 p. 1886.

The list of varieties grown is of interest, especially the Chasselas de Fontainebleau, twenty vines of which produced 1,412 pounds of fruit or about 20 tons per acre. Selected vines of Gros Verdot did even better.

27. Colorimetric measurement of wines. Bull. 60, 3 p. 1886.

This bulletin introduces Salleron's Vino-Colorimeter to California. Using this instrument Hilgard finds striking differences in the per cent color lost after fermentation among the varieties.

28. Distribution of cuttings and scions. Bull. 62, 3 p. 1886.

Includes a list of 16 resistant stocks available for distribution as cuttings or scions.

29. Experiments on methods of fermentation. Bull. 63, 3 p. 1887.

Nine different methods of fermenting red wines were tried. Submerged-cap fermentations were found best. Hot fermentation was poorest but did not contain less alcohol. Punching down of the cap was obviously necessary.

30. Planting and grafting resistant vines. Bull. 64, 3 p. 1887.

Again Hilgard strongly recommends Vitis californica and blames the poor soil conditions for reported failures. 
31. Shall California make sophisticated wines? Bull. 65, 3 p. 1887.

This is an example of Hilgard's crusading. A Pure Wine Law had been proposed at the legislature and Hilgard wrote this bulletin to set forth the scientific principles underlying the law for the wine industry. He strongly opposed the popular saying that "wine is wine." He opposed the use of water after fermentation and also the use of sugar, neutral (nongrape) spirits, glycerin and color. He approved, however, of the addition of tannin or carbon dioxide, and of pasteurizing.

32. The principles and practice of pasteurizing. Bull. 66, 3 p. 1887.

This bulletin outlines the principles of pasteurizing, recommending a temperature of $150^{\circ} \mathrm{F}$, preventing air contact, and rapid cooling. Hilgard correctly notes that pasteurization gives no protection against re-infection and that no portion of the wine should be overheated. Whether or not pasteurization interferes with aging is still a discussible point. For wines needing a malo-lactic fermentation, however, it obviously does interfere with aging if performed before the malo-lactic fermentation takes place.

33. Misconception of the University viticultural work. Bull. 67, 2 p. 1887.

Hilgard defends the small-sample procedure against a report of the Wine Committee of the Viticultural Convention and condemns their method of examination. The plain words of this bulletin are good examples of Hilgard's argumentative and literary ability. He examines the criticisms, admits some, rejects others, and then denounces the committee for their incomplete work and gently questions their competence.

34. Influence of the mode of fermentation on the color of wines. Bull. 68, 1 p. 1887 .

This is a further report of the samples made in Bulletin 63. Wines fermented at high temperatures lost color more rapidly than wines fermented at low temperatures.

35. Wine colors, and color-wines. Bull. 69, 3 p. 1887.

Analyses are reported showing that varieties were available for producing wellcolored wines in California. Differences in the rate of color loss following fermentation are again reported.

36. Abnormal deposits on vine leaves. Bull. 70, 3 p. 1887.

No identification of the vine disease under investigation is made. The appearance of what was probably Pierce's disease in southern California is reported. (See also Viticultural Report for 1886.) Hilgard's guesses about the cause and remedy were rather wide. He also gives a French treatment for anthracnose of vines.

37. Vintage work and instruction in the viticultural laboratory, 1887. Bull. 74, 3 p. 1887.

Hilgard again states his objectives, and invites students and samples. He also comments on resistant stocks and the varying results of experiments-still leaning to Vitis californica.

38. Difficult fermentations. Bull. 75, 2 p. 1887.

Hilgard discusses how to handle stuck wines, favoring aeration. He correctly distinguishes between the ability of high-sugar, low-acid grapes and of low-sugar, high-acid grapes to complete fermentation at high temperatures.

39. The extraction of color and tannin during red-wine fermentation. Bull. 77, 3 p. 1887.

This original experiment on the extraction of color during fermentation has many practical implications, not all of which are yet understood by California wine makers.

40. The conservation of wines. Bull. 87, 4 p. 1890 .

Hilgard presents a defense of pasteurization. He also quotes the experience of Algerians with the sterilization filtration of wine. He correctly challenges those who object to physical treatment of wine.

41. Port and sherry grapes in California, importation of Italian grapes. Bull. 91, $6 \mathrm{p}$. 1891.

Noting the relatively few grapes planted specifically for dessert wines and the excellent conditions in the San Joaquin Valley for growing such grapes, Hilgard lists fifteen varieties which he considers the best. Three or four would not now be considered good for port or sherry, but the dessert wine industry of the state would produce measurably better wines if it had a supply of the other varieties which 
Hilgard recommended over seventy years ago. Unfortunately, one cannot be as enthusiastic about the forty-eight Italian varieties of grapes he listed. Ferw have proven of any value in this state.

42. The work of the College of Agriculture, and Experiment Stations. Bull. 111, $17 \mathrm{p}$. 1896.

In this bulletin Hilgard defends his educational and experimental work. He summarizes his viticultural work as follows:

The result of the laboratory work has been to establish a definite basis for rational wine-production in this State, by determining both the cultural and wine-making qualities of all of the more important grape-varieties in the several regions where our stations were, or are now located. It is true that the depression under which the wine interest [industry?] has labored for a number of years past, has prevented viticulturists from availing themselves, to any great extent, of the guiding principles established by us; but it is quite certain that in future undertakings of this kind, as well as in any rational winery practice in the immediate future, these facts will have to be taken into definite consideration if the product is to be as good as it can be made under local conditions; as competition as well as critical judging of wines make themselves more plainly felt, such practice must inevitably take precedence of the haphazard, irrational modes of procedure that have so largely prevailed heretofore. Our work in this line represents the largest and most complete systematic investigation of the kind on record thus far in any country.

\section{B. University of California Viticultural Reports}

43. Report of the viticultural work during the seasons 1883-84 and 1884-85, being appendix no. IV to the report for the year 1884. With notes regarding the vintage of 1885-86. State Printing Office, Sacramento. 1886. 210 p.

Hilgard gives here the pertinent data regarding the controversy with the Board of Viticultural Commissioners in 1884 over who was to direct his work. The main portion of the report concerns the composition of musts and the quality of the wines produced from them. The classification of grapes as to origin was an artificial one but probably was as convenient as could then be devised. A number of bulletins on phylloxera are reprinted here together with supplementary material.

44. Report of the viticultural work during the seasons 1885 and 1886, being appendix no. VI to the report for the year 1886. State Printing Office, Sacramento. 1886. $186 \mathrm{p}$.

The conclusion of the controversy with the Viticultural Commissioners is referred to. Numerous additional fermentations are reported. Certain bulletins are also reprinted.

45. Reports of experiments on methods of fermentation and related subjects during the years 1886-87. Advance sheets from the annual report of 1888. State Printing Office, Sacramento. $1888.48 \mathrm{p}$.

This report was printed early probably in order to be presented at the Viticultural Convention of March, 1888. It contains a comparison of the results of fermenting red wines by several methods, a defense of the experimental method, reprints Bulletin 66 on pasteurization, and gives analyses of wines of diluted concentrate. Hilgard makes the important observation that color extraction is usually completed early during red wine fermentation.

46. Report of the viticultural work during the seasons $1887-89$, with data regarding the vintage of 1890 . Part I. Red-wine grapes. Prepared under the direction of E. W. Hilgard by L. Paparelli, being a part of the report of the Regents of the University. State Printing Office, Sacramento. 1892. 345 p.

Hilgard's name is signed to only the first 27 pages but much of the lengthy report on grape varieties is a repetition of Hilgard's earlier work, and the earlier tabular results are incorporated into this report. Even the latter sections on "Preservative and remedial processes applied to wines of warm countries," though "prepared by L. Paparelli," bear the mark of Hilgard's style. Some of the latter part is a reprint of his work on pasteurization. The use of Chamberland filters to replace pasteurization is discussed. 
47. Report of the viticultural work during the seasons $1887-92$, with data regarding the vintages of 1894-95. Part I. a. Red-wine grapes (continued from report of 1892). b. White-wine grapes. c. Raisin and table grapes. Part II. Notes on miscellaneous subjects. Being a part of the report of the Regents of the University. A. J. Johnston, State Printer, Sacramento. 1896. 466 p.

This may be considered Hilgard's opus magnum as far as his viticultural research is concerned. In it he summarizes much of the experimental work which had been accomplished during the previous thirteen years. Bioletti's discussion of fermentation and pure yeasts may not have been closely directed by Hilgard.

C. Other Publications Which Include Material on Viticulture by Hilgard

48. Report on the geology and agriculture of the state of Mississippi. E. Barksdale, Jackson, Miss. 1860. xxiv, $391 \mathrm{p}$.

49. Johnson's new universal cyclopedia. New York, A. J. Johnson \& Son. 1876-78. 4 v. Hilgard contributed articles to Volume 4 (published in 1878) on "Vine Culture" (p. 1161-63) and on "Wines and Wine Making" (p. 1449-51). These are admirable essays: accurate, interesting, and informative. They reveal that Hilgard was very familiar with both subjects. (In this connection it is of interest to note that in Hilgard's library there was a copy of Chaptal's famous book, Chemistry Applied to Agriculture [1845], which he had acquired in 1848. It contains in German script, critical penciled notes on the chemical aspects of agriculture, as well as wine making.) F. A. P. Barnard, then president of Columbia University and one of the editors of the Cyclopedia, but formerly a colleague of Hilgard's at Mississippi, had doubtless arranged for the articles. Hilgard was listed as a contributor in Volume 1, on which work was done as early as 1873 . He is listed there as a professor at Michigan. However, these essays were probably written after Hilgard eame to California, since Volume 4 was not published until 1878. Concerning California wines he wrote that they were "mostly fiery, sweet, and heady, but somewhat deficient in flavor. To a certain degree these defects can, and doubtless will, be remedied by judicious selection of grape varieties [our italies] and appropriate treatment." Little did he then realize how much he was to contribute toward this improvement.

50. Lecture on the phylloxera or grapevine louse. Univ. California Bull. 23. January, $1876.24 \mathrm{p}$.

The first systematic report in California on the newly discovered disease.

51. Reports to the President of the University from the College of Agriculture and the Mechanic Arts. State Printing Office, Sacramento. 1877. 80 p.

Hilgard's report covered 63 of the pages. Two viticultural problems are mentioned: a black-knot disease of vines and the production of grape syrup.

52. Report of the Professor of Agriculture to the President of the University. Supplement to the Biennial Report of the Board of Regents. State Printing Office, Sacramento. $1879.113 \mathrm{p}$.

Viticulture has a special section in this report. The late depression in wine prices was blamed on the poor wines produced; better varieties and methods of production were urged. Hilgard also discussed wine aging, brandy and phylloxera.

53. The phylloxera or grapevine louse, and the remedies for its ravages. Supplement no. 1, to the report of the Board of Regents. Univ. California Coll. Agr. 1880. 25 p.

This is a revision of Hilgard's lecture on phylloxera delivered before the State Viticultural Association in San Francisco on November 23, 1875. This was first printed as Bulletin 23 of the University of California (not of the College of Agriculture) in 1876 (see above). About the only new material is Hilgard's advocation of Vitis californica as "at this time a most satisfactory solution of the question of resistant stocks for the vineyards of the future" (p. 25). It is also reprinted in the Viticultural Report for 1883-84 and 1884-85.

54. The permanent maintenance of our vineyards. Address delivered at a meeting of the Napa Viticultural District, held at St. Helena, December 18, 1880. In First Annual Report of the Board of State Viticultural Commissioners. Edward Bosqui \& Co., San Francisco. 1881. P. 57-66. (A second and revised edition was issued in 1881. No place of publication or printer is given. Hilgard's address appears without change on p. 75-84 of this edition.) 
The general outline of Hilgard's future viticultural research appears here for the first time. Most of the speech was on soils. He concluded: "Be sure to strive first and foremost for the establishment of the reputation of California wines both for quality and purity, rather than for quantity per acre."

55. Report of the Professor in charge to the Board of Regents, being a part of the report of the Regents of the University, 1880. State Printing Office, Sacramento. 1881. 108 p.

The viticultural work is summarized in appendices 8 and 9, p. 83-108. The "plan of work" given here was probably written after the St. Helena address mentioned above. It was reprinted in subsequent reports almost unchanged.

56. Report on the climatic and agricultural features and the agricultural practice and needs of the arid regions of the Pacific slope. E. W. Hilgard, T. C. Jones, and R. W. Furnas. Government Printing Office, Washington. 1882. $182 \mathrm{p}$.

Hilgard was chairman of the Commission appointed by the Commissioner of Agriculture. The report includes a brief summary (p. 109-115) of the judging at the Mechanics' Institute in San Francisco in 1878. Hilgard's "unofficial" report reveals that he was well aware of the influence of the hot California climate on the composition of grapes.

57. Report of the Professor in charge to the President, being a part of the report of the Regents of the University, 1882. State Printing Office, Sacramento. 1883. 179 p.

Appendix IV (p. 122-170) deals with viticulture and the rapidly expanding varietal work. Actually F. W. Morse wrote a considerable portion of this report.

58. California wines and brandies. U. S. Dept. Agr. Rept. 20. 1882. P. 109-115.

This is a report of Hilgard's participation in the tasting of wines at the Mechanies' Institute in 1878. Of the 43 samples 32 were placed in the first class. General H. M. Naglee's brandies also received high praise. Some of F. W. Morse's analyses of 1880 and 1881 were given.

59. California State Viticultural Convention. 3rd.

1884. Report of the Third Annual State Viticultural Convention, held at Irving Hall, December 1884. The San Francisco Merchant, San Francisco. [1884\%] 184 p.

60. The future of grape-growing in California. Overland Monthly 3(2):1-6. 1884 .

Hilgard was already predicting another viticultural depression because of the poor quality of many California wines.

61. California State Viticultural Convention. 5th.

1887. Report of the Fifth Annual State Viticultural Convention, held at the Grand Hotel, San Francisco, March 7, 8, 9, 10, 11, 1887, under the auspices of the Grape Growers' and Wine Makers' Association of California. Bacon \& Company, San Francisco. [1887 ] $^{2} 88 \mathrm{p}$.

62. California State Viticultural Convention. 6th.

1888. Report of the Sixth Annual State Viticultural Convention, March 7, 8, 9, 10, 1888 , under the auspices of the Board of State Viticultural Commissioners. State Printing Office, Sacramento. $218 \mathrm{p}$.

63. Plain talk to winemen. San Francisco Examiner. Aug. 8, 1889, p. 4.

Hilgard, in this letter to the Examiner, is very blunt about what is wrong with California wines.

64. Report on the Agricultural Experiment Stations of the University of California with descriptions of the regions represented. State Printing Office, Sacramento. 1890. 204 p.

This report gives a good review of the viticultural work accomplished by the University up to this time (p. 44-47). A list of the 147 varieties of grapes then under trial at the Experiment Stations is given.

NoтE: Miscellaneous material on viticulture may also be found in Hilgard's biennial reports as Professor of Agriculture or as Director of the Experiment Station. Those not listed above contain mainly administrative information on viticulture. See especially Reports of Work of the Agricultural Experiment Station of the University of California for $1890,1892-93,1894-95,1895-96,1897-98,1899-1900,1901-03$ and 1903-04. 

The journal Hilgardia is published at irregular intervals, in volumes of about 600 pages. The number of issues per volume varies.

Subscriptions are not sold. The periodical is sent as published only to libraries, or to institutions in foreign countries having publications to offer in exchange.

You may obtain a single copy of any issue free, as long as the supply lasts; please request by volume and issue number from:

\author{
Agricultural Publications \\ 207 University Hall \\ 2200 University Avenue \\ Berkeley 4, California
}

The limit to nonresidents of California is 10 separate issues on a single order. A list of the issues still available will be sent on request. 